\title{
The response of the Peruvian Upwelling Ecosystem to centennial-scale global change during the last two millennia
}

\author{
R. Salvatteci ${ }^{1,2, *}$, D. Gutiérrez ${ }^{2,3}$, D. Field ${ }^{4}$, A. Sifeddine ${ }^{1,5,6}$, L. Ortlieb $^{1,3,6}$, I. Bouloubassi ${ }^{7}$, M. Boussafir ${ }^{8}$, \\ H. Boucher ${ }^{1,6}$, and F. Cetin ${ }^{1,6}$
}

${ }^{1}$ LOCEAN, UMR7159 (IRD, CNRS, UPMC, MNHN), Institut Pierre Simon Laplace, Laboratoire d'Océanographie et du Climat: Expérimentations et Analyses Numériques, Centre IRD France Nord, 32 avenue Henri Varagnat,

93143 Bondy CEDEX, France

${ }^{2}$ Instituto del Mar del Perú (IMARPE), Dirección General de Investigaciones Oceanográficas y Cambio Climático, Esquina Gamarra y General Valle s/n, Callao, Perú

${ }^{3}$ Universidad Peruana Cayetano Heredia, Programa de Maestría en Ciencias del Mar, Av. Honorio Delgado 430, Urb. Ingeniería, S.M.P., Lima, Perú

${ }^{4}$ Hawaii Pacific University, College of Natural Sciences, 45-045 Kamehameha Highway, Kaneohe, Hawaii, 96744-5297, USA

${ }^{5}$ Departamento de Geoquimica, Universidade Federal Fluminense, Niteroi, Brasil

${ }^{6}$ LMI PALEOTRACES - Institut de recherche pour le développement, France; Universidade Federal Fluminense, Niteroi, Brasil; Universidad de Antofagasta, Chile

${ }^{7}$ LOCEAN, UMR7159 (IRD, CNRS, UPMC, MNHN), Institut Pierre Simon Laplace, Laboratoire d'Océanographie et du Climat: Expérimentations et Analyses Numériques, Université P. et M. Curie, 4 place Jussieu, P.O. Box 100,

75252 Paris cedex 05, France

${ }^{8}$ Institut des Sciences de la Terre d'Orléans, UMR7327 - INSU/CNRS/BRGM/Université d'Orléans, 1A rue de la férollerie, 45071 Orléans CEDEX-2, France

* present address: Institute of Geoscience, Department of Geology, Kiel University, Ludewig-Meyn-Str. 10, 24118 Kiel, Germany

Correspondence to: R. Salvatteci (renatosalvatteci@gmail.com)

Received: 29 August 2013 - Published in Clim. Past Discuss.: 30 September 2013

Revised: 12 February 2014 - Accepted: 23 February 2014 - Published: 9 April 2014

\begin{abstract}
The tropical Pacific ocean-atmosphere system influences global climate on interannual, decadal, as well as longer timescales. Given the uncertainties in the response of the tropical Pacific to increasing greenhouse gasses, it is important to assess the role of the tropical Pacific climate variability in response to past global changes. The Peruvian Upwelling Ecosystem (PUE) represents an ideal area to reconstruct past changes in the eastern tropical Pacific region because productivity and subsurface oxygenation are strongly linked to changes in the strength of the Walker circulation. Throughout the last 2000 years, warmer (the Roman Warm Period - RWP; the Medieval Climate Anomaly - MCA; and the Current Warm Period - CWP), and colder (the Dark Ages Cold Period - DACP - and Little Ice Age - LIA) intervals were identified in the Northern Hemisphere $(\mathrm{NH})$. We
\end{abstract}

use a multi-proxy approach including organic and inorganic proxies in finely laminated sediments retrieved off Pisco $\left(\sim 14^{\circ} \mathrm{S}\right)$, Peru to reconstruct the PUE response to these climatic periods. Our results indicate that the centennial-scale changes in precipitation are associated with changes in the Intertropical Convergence Zone (ITCZ) meridional displacements and expansion/contraction of the South Pacific Subtropical High (SPSH). Additionally, during the NH cold periods, the PUE exhibited an El Niño-like mean state, characterized by a weak oxygen minimum zone (OMZ), and low marine productivity. In contrast, during the RWP, the last stage of the MCA and the CWP, the PUE exhibited a $\mathrm{La}$ Niña-like mean state, characterized by an intense OMZ and high marine productivity. Comparing our results with other relevant paleoclimatic reconstructions revealed that changes 
in the Walker circulation strength and the SPSH expansion/contraction controlled marine productivity and OMZ intensity changes during the past two millennia.

\section{Introduction}

The tropical Pacific ocean-atmosphere system influences global climate on interannual to decadal (Philander, 1990; Bratcher and Giese, 2002), as well as longer timescales with profound long-term effects (Koutavas et al., 2002; Kienast et al., 2006; Partin et al., 2007). The response of the tropical Pacific to the ongoing accumulation of greenhouse gases is uncertain. Some studies suggest that the atmospheric east-west Walker circulation in the tropical Pacific weakened during the 20th century and would further decrease under a warmer climate (Vecchi et al., 2006). By contrast, recent studies suggest that there is no trend in the tropical Walker circulation (Compo et al., 2011) or even that the tropical Pacific trade winds strengthened in the past two decades probably due to a warming of the Indian Ocean relative to the Pacific (Luo et al., 2012). It is therefore important to determine the role of the tropical Pacific climate variability in response to past global natural changes, and to understand the underlying mechanisms (Graham et al., 2011).

Paleoclimate reconstructions, primarily within the Northern Hemisphere (NH), yield some general global-scale patterns that are widely referred to, although it is well known that there is considerable departures from these general Northern Hemisphere patterns on a regional scale (PAGES 2k Network, 2013). Therefore, it is of great interest to know the role of regional phenomenon during periods of average Northern Hemisphere anomalies. Throughout the past 2000 years, periods of warmer climate in the Northern Hemisphere (the Roman Warm Period - RWP, from $\sim \mathrm{AD} 50$ to AD 400, the Medieval Climate Anomaly - MCA, from $\sim \mathrm{AD} 900$ to $\mathrm{AD} 1350$ ) have alternated with colder periods (the Dark Ages Cold Period - DACP, from AD 500 to AD 900 - and the Little Ice Age - LIA, from AD 1500 to AD 1850) (Lamb, 1995; Mann et al., 2009; Graham et al., 2011). The general long-term cooling trend ended late in the 19th century, and the last century (the Current Warm Period CWP, from $\sim 1900$ to the date) was the warmest period during the past two millennia except in Antarctica (PAGES 2k Network, 2013).

The Peruvian Upwelling Ecosystem (PUE) represents an ideal area to reconstruct past changes in the eastern tropical Pacific because upwelling intensity, productivity and subsurface oxygenation are strongly linked to displacements of the South Pacific Sub-tropical High (SPSH) and changes in the strength of the Walker circulation at interannual timescales (Philander, 1990). The PUE is one of the most productive zones in the tropical Pacific, but detailed paleoceanographic reconstructions with well-constructed age models exist only for the past 600 years, showing large climatic, oceanographic and biogeochemical changes. Paleoceanographic reconstructions off central Peru show that a dramatic reduction of export production occurred during the LIA, associated with a weak Oxygen Minimum Zone (OMZ) compared to the last $\sim 100$ years (Sifeddine et al., 2008; Gutiérrez et al., 2009). The lower productivity off Peru during the LIA was associated with an increase in terrestrial input, suggesting higher precipitation in Peru, as also inferred from continental records (Reuter et al., 2009; Bird et al., 2011). The PUE response to the LIA was interpreted to be a result of a mean southward displacement of the ITCZ and a reduced influence of the SPSH along the Peruvian margin (Sifeddine et al., 2008; Gutiérrez et al., 2009). The present study builds upon previous work (e.g., Sifeddine et al., 2008; Gutiérrez et al., 2009, 2011) to determine if such responses of the PUE are consistent during other anomalous periods of mean Northern Hemisphere climate.

The few paleoceanographic reconstructions off Peru covering longer time periods show conflicting results and different climatic interpretations, most likely due to problems associated with the age models developed in each sediment core. The MCA was inferred as a period with low climate variability, of extreme drought, and with persistently weak El Niño activity (Rein et al., 2004). In addition, Agnihotri et al. (2008) showed that during the MCA the subsurface denitrification was lower than at the start of the LIA, and that oceanographic changes during this period were of minor intensity. In contrast to the hypothesis of a period with low climate variability during the MCA (Rein et al., 2004; Agnihotri et al., 2008), a biomarker study off Callao showed that the early part of the MCA was associated with lower El Niño activity, while during the latter half of the MCA both El Niño and La Niña intensified (Makou et al., 2010). Taken together, several works suggest that the MCA (LIA) was characterized by a La Niña-like (El Niño-like) mean state condition and lower El Niño (La Niña) activity (e.g., Rein et al., 2004; Sifeddine et al., 2008; Gutiérrez et al., 2009; Makou et al., 2010). However, a direct comparison of different proxies from different records off Peru should be made with caution, because of chronological problems (e.g., varying reservoir ages in space and time), as well as problems with the stratigraphy of each core (Salvatteci et al., 2014). Moreover, the response of the PUE to climate changes during older periods, like the RWP and DACP, has only been assessed to a limited extent (Rein et al., 2005; Agnihotri et al., 2008).

To date there is still some uncertainty over the predominant mechanisms controlling marine productivity in the PUE at centennial timescales. Two important mechanisms have been suggested: changes in the Walker circulation strength, and changes in the expansion/contraction of the SPSH (Gutiérrez et al., 2009). Changes in the SST gradient across the tropical Pacific, driven by variations in total solar irradiation, can produce large changes in the Walker circulation (Clement et al., 1996; Mann et al., 2009). Several 
studies suggest a stronger (weaker) Walker circulation during the MCA (LIA), inducing a La Niña (El Niño)-like mean state (Cobb et al., 2003; Mann et al., 2005, 2009; Oppo et al., 2009; Conroy et al., 2009, 2010). Under this scenario, the PUE should present higher productivity during the $\mathrm{NH}$ warm periods (RWP and MCA) compared to the NH cool periods (DACP and LIA). On the other hand, the southern range of the SPSH also experienced important meridional displacements during the last two millennia as inferred from the meridional changes in the position of the Southern Westerlies (Lamy et al., 2001; Mohtadi et al., 2007; Moy et al., 2009; Koffman et al., 2013), suggesting changes in the SPSH expansion/contraction. According to this idea, the SPSH contracted during the cold periods (DACP and LIA) and expanded during the RWP and part of the MCA (Lamy et al., 2001). Accordingly, we would expect higher marine productivity off Peru during the warm RWP (expanded high pressure) and part of the MCA, while the opposite is expected for the cold DACP and cool LIA.

In the present study we investigate the response of the PUE to centennial scale changes in Walker circulation strength and the expansion/contraction of the SPSH during the last two millennia. We use a multi-proxy approach including organic and inorganic proxies in finely laminated sediments retrieved off Pisco, Peru. We reconstruct several key aspects of the PUE: OMZ intensity and productivity, along with precipitation, all of which are strongly linked to ocean-atmosphere circulation. First, we reconstruct the terrigenous input to assess if precipitation over the continent is more associated with changes in the ITCZ meridional displacement and SPSH expansion/contraction than changes driven by strong zonal (El Niño-like) shift of precipitation (Gutiérrez et al., 2009). Next, the intensity of the OMZ is reconstructed as it fuels the euphotic layer with nutrients through upwelling. If OMZ intensity were regulated by remote forces (i.e., changes in ventilation and/or water masses) instead of local productivity (Pennington et al., 2006), we would expect the water column oxygenation to have a weaker relationship with the inferred regional productivity. Additionally, we reconstruct oxygen availability in the sediments because a decoupling between the oxygen content in the water column and the sediments may imply changes in the circulation pattern of bottom water masses. Finally, two different types of export production are reconstructed: siliceous productivity and overall export production, which includes export production from higher trophic levels.

The objectives of this work are twofold: first, we set out to define the centennial mean state (El Niño/La Niñalike) of the PUE in contrasting NH warm and cool periods, and during the CWP. At interannual timescales, a reduction of the Walker circulation during El Niño events results in an increase in sub-surface oxygenation and reduced productivity off Peru due to a deepening of the thermocline, whereas the opposite is the case for La Niña events. Following the observed changes at interannual timescales, the multidecadal- to centennial-scale periods with strong (weak) OMZ, and higher (lower) export production are defined in the present work as persistent La Niña (El Niño)-like states. Second, the results of the present work are compared with records of changes in Walker circulation strength and SPSH expansion/contraction to assess the influence of changes in these systems over the PUE.

\section{Environmental setting}

\subsection{Characteristics of the Peruvian Upwelling Ecosystem}

The PUE is an eastern boundary upwelling system characterized by a shallow surface mixed layer, a shallow thermocline and high productivity driven by coastal upwelling of nutrientrich cold waters that are poorly ventilated (Pennington et al., 2006). In the PUE, the seasonal production cycles are out of phase with seasonal increases in upwelling winds, in clear contrast to the other eastern boundary upwelling systems (Pennington et al., 2006; Chavez and Messié, 2009). Upwelling favorable winds occur during the entire year but are stronger during austral winter and spring (Strub et al., 1998; Echevin et al., 2008). By contrast, primary productivity is higher during austral spring and summer when surface waters are more stratified (Pennington et al., 2006; Chavez and Messié, 2009). The seasonal variability of the mixed layer depth is the main controlling factor of the primary productivity seasonality (Echevin et al., 2008). In austral winter, the mixed layer deepening reduces the concentration of chlorophyll because of a dilution effect and light limitation, while during the austral summer the primary producers concentrate near the surface in the shallow mixed layer and nitrate limitation occurs (Echevin et al., 2008). The seasonal changes in winds and productivity in the PUE are associated with the meridional displacement of the eastern SPSH from $\sim 32^{\circ} \mathrm{S}$ in austral summer to $\sim 28^{\circ} \mathrm{S}$ in austral winter (Karstensen and Ulloa, 2009). The ITCZ also shows a seasonal latitudinal displacement from $2-5^{\circ} \mathrm{N}$ in austral summer to $10^{\circ} \mathrm{N}$ in austral winter (Fig. 1; Strub et al., 1998).

The upwelling intensity is not the only factor that maintains productivity in the PUE, but also the supply of nutrientrich and oxygen-poor waters to the region via the Poleward Undercurrent located between $\sim 50$ and $>400 \mathrm{~m}$ depth (Karstensen and Ulloa, 2009). As a combination of lack of ventilation, long residence times, and the decay of biological production that consumes $\mathrm{O}_{2}$, a strong and shallow $\mathrm{OMZ}$ is present off Peru, intersecting the upper continental margin from $\sim 50$ to $600 \mathrm{~m}$ depth (Helly and Levin, 2004; Pennington et al., 2006). This strong OMZ inhibits bioturbation and preserves sediments containing millimeter-scale laminae that permit the reconstruction of past ecosystem changes at high-resolution levels (Gutiérrez et al., 2006). The Poleward Undercurrent is fed by the Equatorial Current System, the 

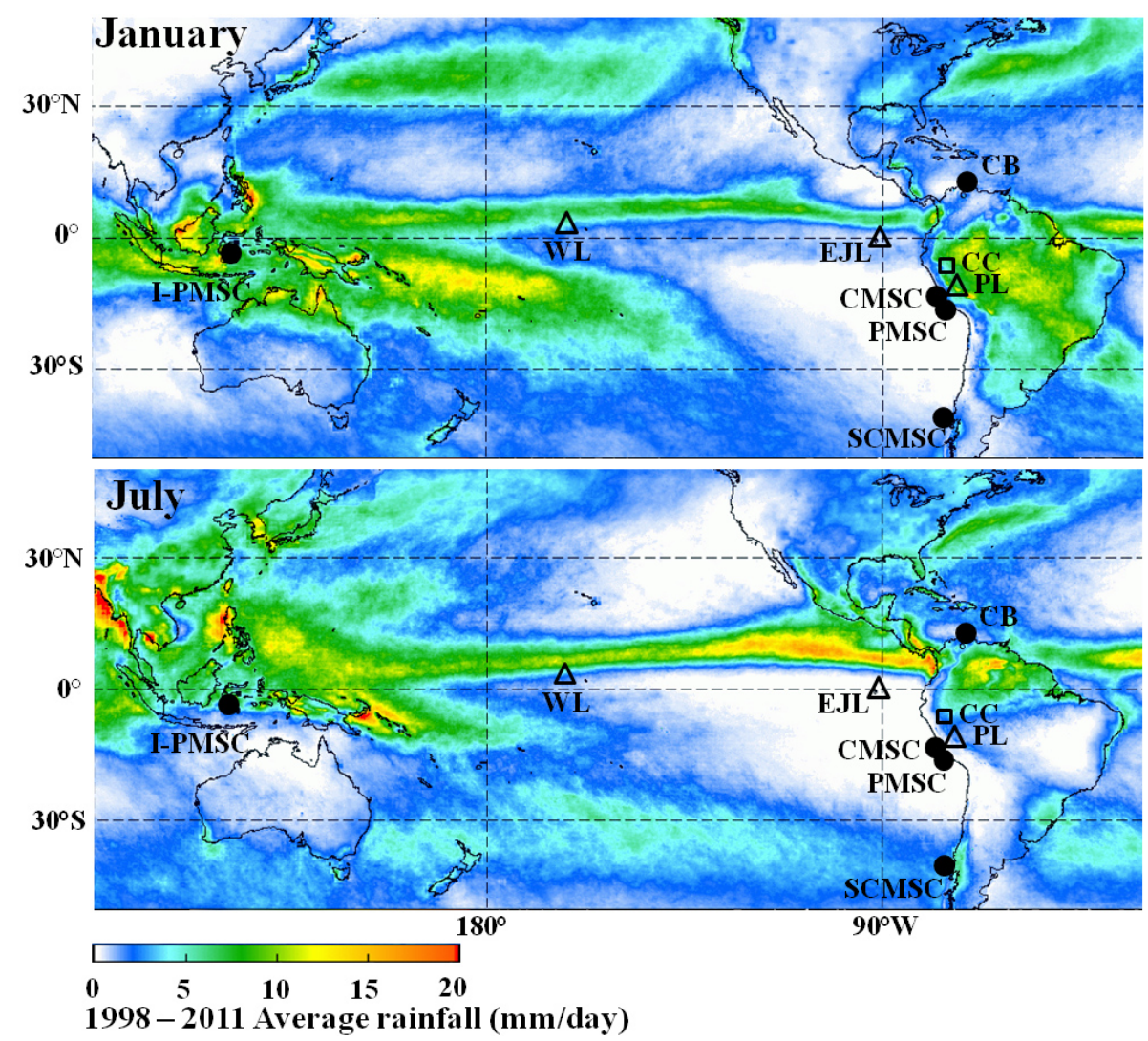

Fig. 1. Seasonal changes in mean precipitation derived from the Tropical Rainfall Measuring Mission (TRMM). Figures modified from the NASA/GSFC website available at http://trmm.gsfc.nasa.gov/. Top panel: mean precipitation during austral summer. Bottom panel: mean precipitation during austral winter. The symbols and abbreviations indicate the position and the records as discussed in the text: I-PMSC, Indo-Pacific Marine sediment core (Oppo et al., 2009); WL, Washington Lake (Sachs et al., 2009); CB, Cariaco Basin (Haug et al., 2001); EJL, El Junco lake (Conroy et al., 2009); CC, Cascayunga cave (Reuter et al., 2009); PL, Pumacocha lake (Bird et al., 2011); CMSC, Callao marine sediment core (Rein et al., 2005); PMSC, Pisco marine sediment cores (the present study); SCMSC, Southern Chile marine sediment core (Lamy et al., 2001). The circles indicate the marine sediment cores, the square indicates the speleothem, and the triangles indicate the lake sediment cores.

Equatorial Undercurrent, Southern Subsurface Countercurrents, alongshore recirculation, and currents located south of $\sim 9^{\circ} \mathrm{S}$ (Montes et al., 2010). Consequently, changes in the intensity and ventilation of these currents can affect the oxygen and nutrient availability in the Poleward Undercurrent that ultimately fuels the euphotic layer via upwelling.

The response of the PUE to centennial-scale global change is not completely understood because of the lack of a widely accepted archival record. Sediment cores collected off Peru are characterized by numerous discontinuities and slumped sections. The reasons for the non-continuous nature of the sedimentary marine record off central Peru are repeated bioturbation events, erosion by bottom currents (Reinhardt et al., 2002), and slumps due to seismic activity (Salvatteci et al., 2014). The numerous discontinuities and slumped/homogeneous sections imply that a cautious and precise core stratigraphy must be developed before any climatic interpretations can be proposed (Salvatteci et al., 2014). Additionally, reconstructions of the PUE lack accurate age model constructions due to varying reservoir ages in space and time

\subsection{Ocean-atmosphere systems driving changes in the PUE}

Changes in the SST gradient across the tropical Pacific (i.e., zonal SST gradient) are a driver for large-scale climate changes off Peru given the tightly coupled system of the Western Pacific warm pool, the East Pacific cold tongue, and Walker circulation (Pierrehumbert, 2000). This zonal SST gradient, between the tropical Indo-Pacific warm pool in the west and the central/eastern tropical Pacific, can be affected by variations in total solar irradiation, resulting in circulation changes driving climate shifts around the planet (Mann et al., 2009; Graham et al., 2011). According to this "thermostat mechanism", increased solar irradiance tends to intensify the east-west temperature gradient, which strengthens the equatorial easterlies and increases the upwelling in 
the equatorial Pacific, amplifying the thermocline tilt towards the east (Clement et al., 1996). The SST asymmetry between the warm Eastern Pacific and cold Eastern Equatorial Pacific is the principal factor controlling the intensity of the Walker circulation along the equator (Bjerknes, 1969). Moreover, the latitudinal position of the ITCZ contributes to the modification of the zonal SST gradient by the expansion/contraction of the Southeast Pacific cold tongue (Koutavas and LynchStieglitz, 2005).

Another factor that influences large-scale climate changes off Peru is the position and strength of the SPSH. The SPSH is bounded to the north by the ITCZ and to the south by the polar front and disturbances along the front (Strub et al., 1998). This atmospheric circulation regulates the strength of the alongshore winds off Peru, forcing the upwelling of subsurface nutrient-rich waters along the Peruvian coast (Aceituno et al., 1993; Strub et al., 1998). The SPSH has shifted poleward and intensified during the last decades, producing higher equatorward winds off Chile (Falvey and Garreaud, 2009). Accordingly, SPSH latitudinal expansions/contractions should also affect the wind intensity off central-southern Peru. The relationship between wind strength and marine productivity is not that straightforward though, because the thermocline/nutricline depth plays a major role. A deep thermocline/nutricline in combination with stronger alongshore winds will likely produce nonproductive upwelling, as for example during El Niño events (Bakun et al., 2010).

\section{Material and methods}

\subsection{Sampling site and cores used in the present study}

Nine gravity and box cores were selected from more than 30 cores to determine the continuity of the records and to select the best cores for analyses (SM1; Salvatteci et al., 2014). All cores were retrieved off Pisco, Peru (Fig. 1), because this area presents finely laminated sequences allowing high-resolution reconstructions (SM1). Given the problems with the sedimentary column continuity (Salvatteci et al., 2014), we applied a detailed stratigraphic approach to construct an accurate age model (SM1 and SM2). After a careful revision of sedimentary characteristics, we selected box core B0506-14 (hereafter B-14) retrieved at $301 \mathrm{~m}$ depth $\left(14.27^{\circ} \mathrm{S}, 76.43^{\circ} \mathrm{W}\right.$; Fig. 1) for the present study as it presented the most continuous, undisturbed, and well-preserved laminae sequences (SM1). The presence of small-scale discontinuities and mixed sequences in B-14 should not affect the centennial scale changes of the proxy records that are the focus of the present work. Core B-14 covers approximately the last $\sim 500$ years, but in order to infer changes prior to the LIA, we analyzed a laminated section from a $5.2 \mathrm{~m}$ long gravity core (G-10), whose upper part overlaps with the bottom of core B-14 (SM1). Core G-10 was retrieved during the Galathea-3 expedition in 2007 at $312 \mathrm{~m}$ depth $\left(14^{\circ} 23^{\prime} \mathrm{S}\right.$, $76^{\circ} 23.9^{\prime} \mathrm{W}$ ) near the B-14 location (Fig. 1).

For a detailed description of the two cores used in this work, the stratigraphic approach, the subsampling procedure, the composition of the assembled core, and the development of the age model, we refer to SM1, SM2 and SM3 in the Supplement.

\subsection{Rationale behind the choice of proxies}

\subsubsection{Terrestrial runoff}

The temporal changes in precipitation over the continent were inferred through the terrestrial detritic contents - Aluminum (Al) and Titanium (Ti) - in the sediment cores. Precipitation run-off erodes fine-grained lithics from soils that are then flushed via rivers into the sea where they are dispersed along the continental shelf by oceanic currents (Rein et al., 2007). The terrigenous material on the shelf is principally delivered by rivers that dilute components of eolian origin (Scheidegger and Krissek, 1982); it can thus be used as a proxy of fluvial discharge. The sedimentary archives on the continental shelf are interpreted to integrate the riverine discharge from the Pacific drainage area along the Peruvian coast. At seasonal timescales, the weakening of the SPSH and the southward displacement of the ITCZ during austral summer induce the development of a rainy season (Garreaud et al., 2009; Lavado et al., 2012). At interannual timescales, during El Niño events, rainfall and runoff along the dry northern Pacific coast are above average, associated with a collapse of the Walker circulation (Lavado Casimiro et al., 2012).

\subsubsection{Redox conditions}

In order to reconstruct sediment redox conditions we used a series of trace elements that exhibit different sensitivities to redox conditions, such as Molybdenum (Mo), Vanadium (V) and Rhenium (Re). This permits the differentiation between anoxic (sulfate reducing) or sub-oxic $\left(0.2>\left[\mathrm{O}_{2}\right]>0 \mathrm{mLL}^{-1}\right.$ and no $\left.\mathrm{H}_{2} \mathrm{~S}\right)$ conditions at the time of deposition. Moreover, Mo, $\mathrm{V}$, and Re are heavily enriched in OMZ sediments off Peru, have minimal detrital influence, and display a conservative behavior in the water column (Colodner et al., 1993; Böning et al., 2004; Tribovillard et al., 2006). Mo is enriched mainly under anoxic, sulfatereducing conditions, when $\mathrm{H}_{2} \mathrm{~S}$ is available (Crusius et al., 1996; McManus et al., 2006; Tribovillard et al., 2006). V is reduced and accumulates under denitrifying conditions but also under more strongly reducing (i.e., anoxic) conditions. Re concentrations in the continental crust and in the seawater are extremely low but are strongly elevated in reducing sediments with absence of $\mathrm{O}_{2}$ and $\mathrm{H}_{2} \mathrm{~S}$ (Crusius et al., 1996; Böning et al., 2004), but also (perhaps to a lesser extent) in sulfidic sediments (Crusius et al., 1996). Mo, V, and Re 
accumulate via diffusion across the sediment-water interface according to the extent of reducing conditions (Böning et al., 2004; Tribovillard et al., 2006; Scholz et al., 2011). Sediments exhibiting concurrent enrichments in $\mathrm{V}, \mathrm{Re}$ and $\mathrm{Mo}$ reflect euxinic conditions $\left(\left[\mathrm{O}_{2}\right]=0\right.$; presence of $\left.\mathrm{H}_{2} \mathrm{~S}\right)$ at the sediment-water interface, whereas an enrichment of Re (and also $\mathrm{V}$ to a lesser extent) without Mo enrichment reflects suboxic (absence of $\mathrm{H}_{2} \mathrm{~S}$ ) conditions (Tribovillard et al., 2006). Thus, the Re/Mo ratio can be used to differentiate anoxic from sub-oxic conditions. A ratio similar to $0.4 \times 10^{-3}$ corresponds to the ratio of these two elements in the seawater (Crusius et al., 1996) and anoxic conditions in the sediments with a presence of $\mathrm{H}_{2} \mathrm{~S}$ can be inferred, whereas values above $0.4 \times 10^{-3}$ reflect sub-oxic conditions.

\subsubsection{Export production}

Export production is inferred using a set of proxies that represent different types of productivity. Biogenic silica contents were analyzed in order to infer primary production that exclusively originated from siliceous biota, such as diatoms, radiolaria, siliceous sponges, and silicoflagellates (DeMaster, 1981). Nickel (Ni), Copper (Cu) and Cadmium (Cd) are expected to represent export production because they display a nutrient-like behavior in the water column, are present in considerable concentrations in plankton, and it seems that the dominant source of these elements is bio-detritus (Böning et al., 2004; Nameroff et al., 2004; Dean et al., 2006; Tribovillard et al., 2006). Ni, $\mathrm{Cu}$ and $\mathrm{Cd}$ are frequently used as proxies of the original presence of organic matter $(\mathrm{OM})$; these elements are delivered to the sediments in association with $\mathrm{OM}$ and fixed in the sediments under reducing conditions (Böning et al., 2004; Dean et al., 2006; Tribovillard et al., 2006). Cd is heavily enriched in marine sediments off Peru, while $\mathrm{Ni}$ and $\mathrm{Cu}$ are moderately enriched (Böning et al., 2004). Total organic carbon (TOC) was also analyzed to reconstruct export production and to examine the relationship with the productivity proxies. $\mathrm{Ni}, \mathrm{Cu}, \mathrm{Cd}$, and TOC should reflect the export production from the euphotic zone that escapes remineralization in the upper meters of the water column. This export production is basically composed of large particles like fecal pellets or large marine snow (Suess, 1980). It is not a simple function of productivity since it is highly dependent on the pelagic community structure and trophic pathways (Michaels and Silver, 1988; Rodier and Le Borgne, 1997), thus also representing biomass variability of higher trophic levels.

\subsubsection{Water column denitrification}

Water column denitrification is inferred through the analysis of $\delta^{15} \mathrm{~N}$ from sedimentary $\mathrm{OM}$, and generally reflects regional- to large-scale changes (Altabet and Francois, 1994; Altabet et al., 1999; De Pol-Holz et al., 2006; Martinez and Robinson, 2010; Mollier-Vogel et al., 2012). In oxygen-deficient waters, bacteria reduce nitrate to $\mathrm{N}_{2}$, leaving the remaining nitrate pool enriched in ${ }^{15} \mathrm{~N}$, which is upwelled to the surface, where it is used by phytoplankton and ultimately transferred to the sediments (Altabet and Francois, 1994; Agnihotri et al., 2008). However, several other factors can contribute to the $\delta^{15} \mathrm{~N}$ signal in the sedimentary organic matter, like $\mathrm{N}_{2}$ fixation by diazotrophic bacteria, nitrification, the extent of surface $\mathrm{NO}_{3}^{-}$utilization, and the anammox reaction (Robinson et al., 2012). Nevertheless, the sedimentary $\delta^{15} \mathrm{~N}$ signal off Peru is consistent with other proxies of oxygenation and productivity, implying denitrification in the water column at least during the last millennia (Agnihotri et al., 2008; Gutiérrez et al., 2009).

\subsection{Analytical procedures}

Sediment accumulation rates were assessed through downcore profiles of ${ }^{210} \mathrm{~Pb}$ and ${ }^{241} \mathrm{Am}$ for the last 150 years, and with radiocarbon ages for the rest of the record. ${ }^{210} \mathrm{~Pb}$ and ${ }^{241} \mathrm{Am}$ activities were measured on $1-2 \mathrm{~g}$ of dried sediments by gamma spectrometry using high efficiency, verylow-background well-type Germanium detectors (Reyss et al., 1995) in the underground laboratory of Modane (France). ${ }^{226} \mathrm{Ra}$ activities were inferred from gamma spectra and then the ${ }^{210} \mathrm{~Pb}_{\text {ex }}$ activity was calculated by subtracting the ${ }^{226} \mathrm{Ra}$ from the total ${ }^{210} \mathrm{~Pb}$ activity (Appleby, 2001). Bulk organic matter radiocarbon measurements were performed by accelerator mass spectrometry (AMS) at the "Laboratorie de mesures du Carbone-14" (LMC14, Gif-sur-Yvette, France).

Major elements ( $\mathrm{Al}$ and $\mathrm{Ti})$ and trace elements $(\mathrm{Mo}, \mathrm{V}$, $\mathrm{Re}, \mathrm{Cd}, \mathrm{Ni}$ and $\mathrm{Cu}$ ) were analyzed by ICP-MS (Ultramass Varian) after hot-plate acid digestion. The measurement precision was determined by performing duplicate analyses. The average values of replicate digestions were well within the recommended ranges with relative standard deviations (RSD) being $<1 \%$ for $\mathrm{Al}, \mathrm{Ti}, \mathrm{Mo}, \mathrm{V}, \mathrm{Ni}$ and $\mathrm{Cu}$, and $<2.5 \%$ for $\operatorname{Re}(n=229)$. The biogenic silica was quantified by Fourier-transformed infrared spectrometry (FTIR) analyses (Bertaux et al., 1998). FTIR and ICP-MS analyses were performed at the ALYSES laboratory (Bondy, France). The quantification of organic matter was done using Rock-Eval 6 (Lafarge et al., 1998), at the "Institut des Sciences de la Terre d'Orleans". $\delta{ }^{15} \mathrm{~N}$ analyses were measured on a continuousflow gas-ratio mass spectrometer at ALYSES and at the Department of Geosciences of the University of Arizona. For a detailed description of the analytical procedures we refer to SM4 in the Supplement.

\subsection{Statistical procedures}

To establish the relationships among the different proxies, we calculated Pearson correlation coefficients $(r)$ using the Statistica software (Statsoft, 2005). The probability level was corrected for multiple comparisons dividing the probability level $\alpha(p<0.05)$ by the number of tests performed (Glantz, 
2002). Given that 12 tests were performed, the corrected probability level was $p<0.0042$.

\section{Results}

\subsection{Data presentation}

The downcore changes in the proxies for terrestrial runoff (Al and Ti), water column oxygenation $\left(\delta^{15} \mathrm{~N}\right)$, redox conditions (Mo, V, Cd, $\mathrm{Re}$, and $\mathrm{Re} / \mathrm{Mo}$ ) and export productivity (biogenic silica, TOC, $\mathrm{Ni}$ and $\mathrm{Cu}$ ) are shown as anomalies in Fig. 2. The differences in sedimentation rates (among periods) and the different subsampling thickness (between cores) indicated that the average time span of each sampled interval during the RWP, DACP, MCA, LIA and CWP was 21.9, 21.9, 7.5 and 1.1 years, respectively. Consequently, samples corresponding to the LIA and CWP periods were lumped into intervals of approximately 20 years, and the results are presented as standardized values (value-average/sd). The standardized authigenic concentrations of the trace elements were used instead of the Al normalization or metal accumulation rates. Normalization of trace element concentrations through division by $\mathrm{Al}$ as well as the calculation of fluxes (metal concentration $\times$ sedimentation rates $\times$ DBD) are common practices. However, in the present data set, the normalization procedure increased, decreased, or even changed the sign of the correlations between unmodified variables (SM8). The large variations in sedimentation rates (SM3) also produced distorted correlations between elements (data not shown). Consequently, we present the authigenic concentrations of the trace elements instead of metal fluxes or Al normalization. Nonetheless, we calculated the average enrichment factor of each element in the whole record to determine the elements with the highest enrichments relative to andesite (SM9, SM10). The high and moderate enrichment factors of $\mathrm{Re}, \mathrm{Cd}, \mathrm{Mo}, \mathrm{Ni}$, and $\mathrm{V}$ support their use as paleoredox or paleoproductivity proxies.

\subsection{Terrestrial runoff}

The low concentrations of $\mathrm{Al}$ and $\mathrm{Ti}$ indicate drier conditions during several $\mathrm{NH}$ warm periods, such as the last stage of the MCA ( AD 1170 to $\mathrm{AD} 1350)$ and the last 150 years (Fig. 2a and b). There are generally more humid conditions during the NH cold periods, such as during the DACP and much of the LIA, although there are some exceptions to these generalities. In our record, the MCA shows two periods with strong differences in terrestrial input: a period with high values from $\sim \mathrm{AD} 1050$ to $\mathrm{AD} 1170$ and a period with low values from $\sim \mathrm{AD} 1170$ to AD 1350. The LIA shows more humid conditions compared to the dry stage of the MCA and the last 150 years. During the LIA, from AD 1550 to AD 1750, reduced terrigenous input is recorded compared to the start and end of this period, but the values are still higher than during the last stage of the MCA and the CWP. The transition from the MCA to the LIA shows a gradual increase in terrestrial input, while the transition from the LIA to the CWP shows an abrupt decrease as also reported by Sifeddine et al. (2008) and Gutiérrez et al. (2009).

\subsection{Water column oxygenation and sediment redox conditions}

Water column denitrification and the sedimentary redox conditions, particularly Mo and Re/Mo, are strongly coupled throughout the record (Fig. 2c-h), implying low influence of remote oxygenated bottom waters (e.g., Antarctic Intermediate Water). The $\delta^{15} \mathrm{~N}$ profile shows large centennialscale changes suggesting less water column denitrification and hence a weaker OMZ during the NH cold periods (DACP and LIA), and more intense water column denitrification and OMZ during the warmer MCA and CWP (Fig. 2c). The relationships among sediment redox condition proxies show the expected behavior according to their sensitivity to sediment oxygen levels: Mo and Re are negatively correlated, while the relationship between Mo and V is stronger than that between Re and V (SM7 and SM10). Additionally, Cd seems to follow sediment redox conditions instead of export production (SM7 and SM10). Authigenic Mo, V and Cd contents indicate sub-oxic conditions during the $\mathrm{NH}$ cold periods (DACP and LIA), and anoxic conditions during part of the RWP, the last stage of the MCA, and from the end of the LIA to the present (Fig. 2c-h). This pattern is better shown by the $\mathrm{Re} / \mathrm{Mo}$ ratio that serves to effectively differentiate euxinic conditions $\left(\left[\mathrm{O}_{2}\right]=0\right.$; presence of $\left.\mathrm{H}_{2} \mathrm{~S}\right)$ and sub-oxic conditions (Fig. 2h). During part of the RWP, the last stage of the MCA (AD 1170 to AD 1350), and from the end of the LIA until 2005, the Re/Mo values were close to or below $0.4 \times 10^{-3}$, indicating predominant euxinic conditions (dashed line in Fig. 2h). The inferred oxygenation in the sediments was higher during the LIA compared to the DACP (Fig. 2c-h).

During the MCA, we observed two different multi-decadal stages with contrasting behavior of the oxygen content in the water column and the sediment-water interface and (Fig. 2ch). From $\sim$ AD 1050 to $\sim$ AD 1170, higher Re/Mo values and relatively lower $\delta^{15} \mathrm{~N}$ values are consistent with suboxic conditions in the sediment-water interface and a relatively more ventilated water column (but these changes were less intense than during the DACP and the LIA). By contrast, from $\sim \mathrm{AD} 1170$ to $\mathrm{AD} 1350$, there is a concurrent increase in Mo, very low values of Re/Mo (ratios near to $0.4 \times 10^{-3}$ ), and higher $\delta^{15} \mathrm{~N}$, indicating anoxic conditions in the sediment-water interface and an intense OMZ. The two different stages indicate that the MCA was not a homogeneous period in the region, as has also been demonstrated by the terrigenous input record.

The transitions from the NH warm to cold periods show different patterns of oxygenation change than the transitions from the NH cold to warm periods (Fig. 2c-h). The 


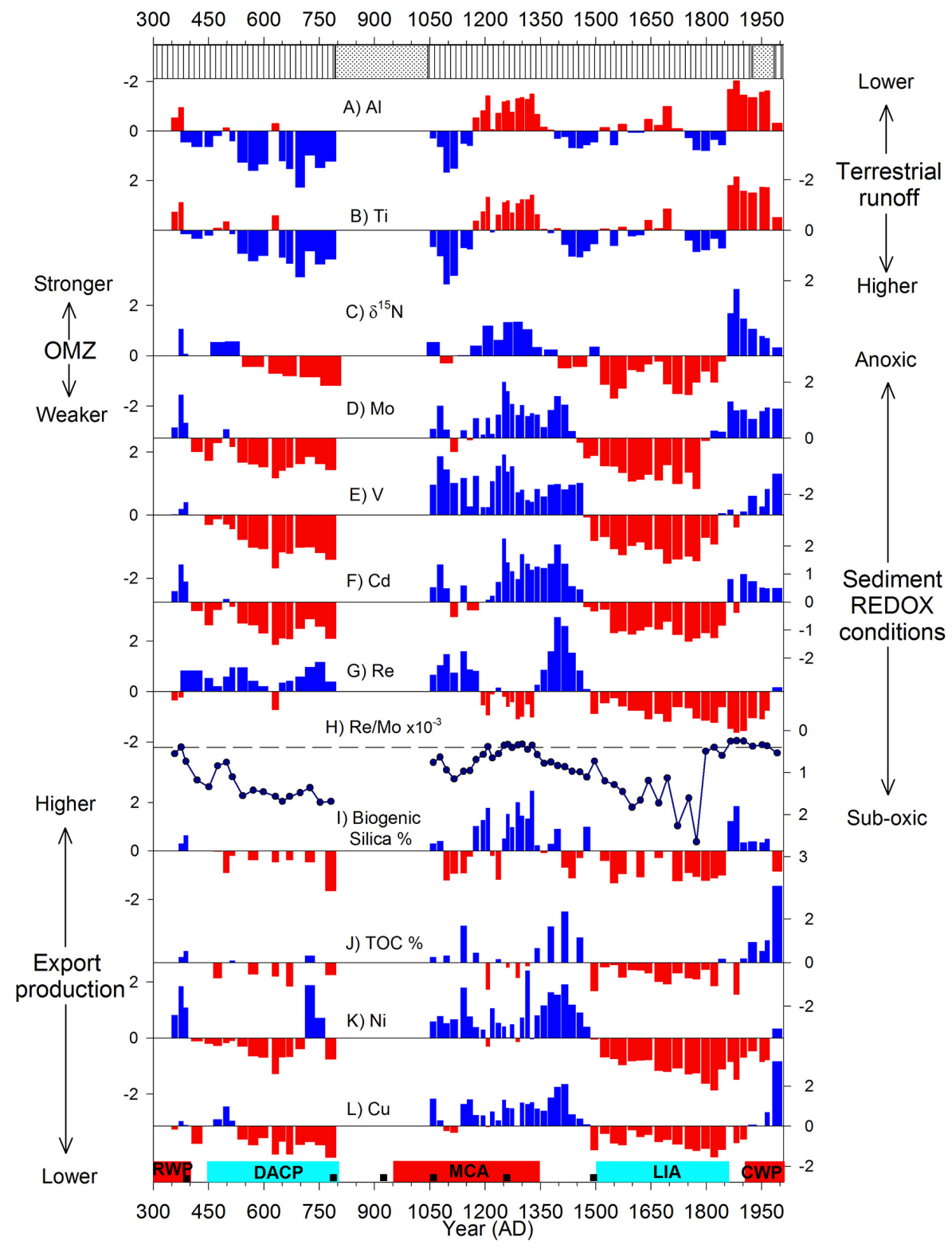

Fig. 2. Standardized values (value-average)/sd) of the proxies evaluated in the present study. (A) Aluminum (Al), (B) Titanium (Ti) proxies for terrestrial runoff. (C) $\delta^{15} \mathrm{~N}$, proxy for water column denitrification. (D) Molybdenum (Mo), (E) Vanadium (V), (F) Cadmium (Cd) and (G) Rhenium (Re), proxies for sediment redox conditions. (H) $\mathrm{Re} / \mathrm{Mo} \times 10^{-3}$, proxy to differentiate euxinic $\left(\left[\mathrm{O}_{2}\right]=0\right.$; presence of $\left.\mathrm{H}_{2} \mathrm{~S}\right)$ versus sub-oxic conditions; the dashed line indicates the seawater value of Re/Mo $=0.4 \times 10^{-3}$ reported by Crusius et al. (1996). (I) Biogenic silica (\%), proxy for siliceous export production. (J) Total organic carbon (TOC), (K) Nickel (Ni) and (L) Copper (Cu) export production proxies. The rectangle at the top of the figure represents a simplified lithology: the areas with vertical lines represent finely laminated sediments and the dotted areas represent mixed sediments or more homogeneous material. The colored boxes at the bottom of the figure indicate the Roman Warm Period (RWP), the Dark Ages Cold Period (DACP), the Medieval Climate Anomaly (MCA), the Little Ice Age (LIA) and the Current Warm Period (CWP). The age intervals of each period were taken from Lamb (1995) and Graham et al. (2011). The small boxes at the bottom of the figure indicate the position of the samples that were dated by ${ }^{14} \mathrm{C}$. The data corresponding to the LIA and CWP were lumped into intervals of $\sim 20$ years to fit the sample resolution of the older periods.

RWP-DACP and MCA-LIA transitions are gradual, whereas the LIA-CWP transition is abrupt (Fig. 2h). The gradual RWP-DACP and MCA-LIA transitions are characterized first by a decrease in Mo and then by a decrease in V (Fig. 2d and e), as expected due to the behavior of these elements to a gradual change from anoxic to sub-oxic conditions. The OMZ also shows a gradual intensity decrease during the RWP-DACP and MCA-LIA transitions as shown by the $\delta^{15} \mathrm{~N}$ profile (Fig. $2 \mathrm{c}$ and h). By contrast, the LIA-CWP transition is characterized by an abrupt decrease in oxygenation 
in the water column and in the sediments as discussed in detail by Gutiérrez et al. (2009).

\subsection{Paleoproductivity proxies}

At centennial to multi-centennial timescales, export production, represented both by biogenic silica and the overall export production proxies (TOC, $\mathrm{Ni}$ and $\mathrm{Cu}$ ), is higher during the NH warm periods (RWP and MCA) and during the CWP, and lower during the NH cool periods (DACP and LIA). However, within the NH warm periods, the flux of biogenic silica and the other export production proxies seem to be out of phase with one another (Fig. 2i-1). For example, biogenic silica is highest during the middle stage of the MCA, whereas TOC and other proxies are higher during the early and latter portions of the MCA. Consistent with the proxies for oxygenation, all paleoproductivity proxies show a gradual decrease during the MCA-LIA transition; however, the start of the decrease pattern is different in the biogenic silica and the other productivity records (Fig. 2i-1). During the LIA-CWP transition, only the biogenic silica contents show an abrupt increase, while the proxies for overall export production show a more gradual increase.

Some relationships among proxies for export production are highly correlated with other productivity proxies whereas others are not, which allows interpreting changes in productivity during the last two millennia. Biogenic silica contents show negative correlations with the other export production proxies, indicating that the overall export production is not a simple function of siliceous productivity, but rather depends on oceanographic conditions. There are generally higher correlations between TOC, $\mathrm{Ni}$, and $\mathrm{Cu}$ than between these and $\mathrm{Cd}$, suggesting that $\mathrm{TOC}, \mathrm{Ni}$, and $\mathrm{Cu}$ may be better indicators of export production. Moreover, the correlations between $\mathrm{Cd}$ and the sediment redox conditions (Mo and $\mathrm{V}$ ) are stronger than the correlations between $\mathrm{Cd}$ and the export production proxies ( $\mathrm{TOC}, \mathrm{Ni}, \mathrm{Cu}$ ), suggesting that $\mathrm{Cd}$ may be a better indicator of sediment redox conditions. For the detailed correlation values, we refer to SM7 and SM10 in the Supplement.

Water column and sediment oxygenation show a stronger relationship with siliceous productivity than with the overall export production proxies, indicating that siliceous productivity and the subsequent sinking and decaying have a higher contribution to the subsurface oxygen deficit (Fig. 2). The biogenic silica contents show high relationships with proxies related to oxygenation in the water column, i.e., $\delta^{15} \mathrm{~N}(0.75$; SM7) and in the sediments, e.g., Mo and Re/Mo (0.50 and -0.58 , respectively; SM7). The higher relationships with the subsurface oxygenation compared to the anoxic conditions in the sediments imply that the biogenic silica record reflects the export of primary productivity and is not a preservation signal regulated by the anoxic conditions in the seafloor, given that the latter is the principal factor regulating the preservation of biogenic silica in the sediments. The highest values of biogenic silica during the MCA (from $\sim \mathrm{AD} 1170$ to $\sim \mathrm{AD} 1350$ ) coincide with a strong water column denitrification and an anoxic episode in the sediments as recorded by the $\delta^{15} \mathrm{~N}$ and the Re/Mo ratio (Fig. 2c and h).

Contrary to the strong relationships between biogenic silica and the proxies for oxygenation, relationships of $\mathrm{Ni}, \mathrm{Cu}$ and TOC with $\delta^{15} \mathrm{~N}$ are negative and weak, and the relationships with sediment redox conditions (Mo and $\mathrm{Re} / \mathrm{Mo}$ ) are very weak (SM7). During the MCA and the CWP, the proxies for overall export production show higher values when the OMZ is less intense (Fig. 2c, j, k and l). For example, the highest values of the overall export production proxies $(\mathrm{Ni}$, $\mathrm{Cu}$ and TOC) prior to the CWP occurred during the MCALIA transition (at $\sim$ AD 1400), 100 years after a period characterized by a strong OMZ (Fig. 2c), and when the trend towards less intense OMZ and more sub-oxic conditions in the sediments had already started (Fig. $2 \mathrm{c}$ and h). During the LIA-CWP transition, the highest values of $\mathrm{Ni}, \mathrm{Cu}$ and TOC (Fig. 2j-1) occurred several decades after the period characterized by the strongest water column denitrification and the development of anoxic conditions on the seafloor (Fig. 2c and $h$ ).

\section{Discussion}

In the present study, we define, for the first time, the mean state of the PUE in contrasting climatic periods at centennial timescales during the past two millennia: the Roman Warm Period (RWP), the Dark Ages Cold Period (DACP), the Medieval Climate Anomaly (MCA), the Little Ice Age (LIA), and the Current Warm Period (CWP). The principal results of the present study are: (1) drier conditions during the last stage of the MCA ( AD 1170 to AD 1350) and the past 150 years, and more humid conditions in the DACP, LIA and from $\sim \mathrm{AD} 1050$ to $\mathrm{AD} 1170$ during the MCA (Fig. 2a and b); (2) a strong oxygen minimum zone (OMZ) and high productivity during the periods of NH warming (RWP, MCA and CWP), whereas during the periods of $\mathrm{NH}$ cooling (DACP and LIA) we observe a weak OMZ and low productivity (Fig. 2); (3) a strong coupling between OMZ intensity and primary productivity; (4) a gradual change from a stronger to a weaker OMZ, and from high to low primary productivity during the RWP-DACP and MCA-LIA transitions, and an abrupt change from a weaker to a stronger OMZ, and from low to high primary productivity during the LIA-CWP transition (see also Gutiérrez et al., 2009). In the following sections we first discuss whether precipitation over the western Andes is more associated with changes in the Intertropical Convergence Zone (ITCZ) meridional displacement and South Pacific subtropical high (SPSH) expansion/contraction than changes driven by strong zonal (El Niño-like) shift of precipitation. Second, we define the El Niño/La Niña mean state during the contrasting time periods and then we evaluate the influence of changes in Walker circulation strength and the SPSH expansion/contraction on the productivity and 
OMZ intensity off Peru during the last two millennia. We focus less on the abrupt change occurring at the end of the LIA because this change is described in great detail by Gutiérrez et al. (2009).

\subsection{Precipitation over Peru is associated with ITCZ displacement}

The precipitation changes in the last two millennia indicated by an average of the standardized $\mathrm{Al}$ and $\mathrm{Ti}$ in sediments from Pisco (present study) are compared with records indicating the position of the ITCZ, the SPSH expansion/contraction, and other continental precipitation records from South America (Reuter et al., 2009; Bird et al., 2011) in Fig. 3. The precipitation changes, indicated in sediments from Pisco (present study), and other continental paleoclimate records from Peru (Reuter et al., 2009; Bird et al., 2011) are very similar and indicate that changes in precipitation took place at a regional scale (Fig. 3). The timing and direction of mean state changes in these records are notable given the different locations, paleoclimate archives, age models, and proxies used in each record. The Cascayunga cave is located in northeast Peru along the eastern margin of the Andes at $930 \mathrm{~m}$ a.s.l. (above sea level) (Fig. 3e; Reuter et al., 2009). Pumacocha Lake is located in the eastern Peruvian Andes at $4300 \mathrm{~m}$ a.s.l. and the lake's hydrological mass balance is dominated by precipitation since there is no fluvial input (Fig. 3f; Bird et al., 2011). Finally, the Pisco record, which is interpreted to integrate the riverine discharge from the Pacific drainage area along the Peruvian coast, confirms the regional centennial-scale changes in precipitation.

Multidecadal changes in precipitation in the Pisco record are strongly associated with major meridional ITCZ variability and SPSH expansion/contraction (i.e., summer-like, winter-like conditions) than changes in the Walker circulation strength (Fig. 3). According to precipitation proxies over the continent (Haug et al., 2001) and in the central Pacific Ocean (Sachs et al., 2009), as well as modeling experiments (Broccoli et al., 2006), the ITCZ exhibited large latitudinal changes throughout the last two millennia, migrating to the north (south) during warm (cold) periods (Fig. 3a, b). Accordingly, the SPSH expanded during the RWP and the last stage of the MCA, and contracted during the DACP and the LIA, associated with meridional changes in the ITCZ position (Fig. 3c, Lamy et al., 2001). Multidecadal- to centennial-scale variability in precipitation in our records (Fig. 3d) follow changes in these atmospheric systems (Fig. 3b and c). The inferred precipitation patterns are consistent with persistent austral winter-like conditions during the RWP, the last stage of the MCA and during the CWP, and with persistent austral summer-like conditions during the DACP, from $\mathrm{AD} 1050$ to $\mathrm{AD} 1170$, and the LIA. If the precipitation changes were more associate with changes in zonal shift of precipitation (i.e., during El Niño events) we should expect lower precipitation during the entire MCA, because the Walker circulation was strong during this entire period (Conroy et al., 2010). Moreover, lower salinity in the Western Pacific prevailed during the LIA and this condition occurs nowadays during austral summer, associated with higher precipitation, but not during El Niño events (Newton et al., 2006).

The results of the present study as well as other precipitation records in Peru (Reuter et al., 2009; Bird et al., 2011) contradict a hitherto widely accepted record of terrestrial runoff studied in Callao, Peru (Fig. 3g; Rein et al., 2004, 2005), but are consistent with regional records of ITCZ displacements (Fig. 3b; Haug et al., 2001; Sachs et al., 2009). Rein et al. $(2004,2005)$ interpreted a period between $\sim \mathrm{AD} 750$ to $\sim \mathrm{AD} 1250$ (in part coinciding with the MCA period) as a dry period in Peru, based on reduced lithic contents in a marine sediment core retrieved off Callao $\left(\sim 12^{\circ} \mathrm{S}\right)$. The radiochronological differences between the Pisco (present study) and Callao (Rein et al., 2004, 2005) records may be partly related to different delta-R estimates. More likely, the differences in the nature of the MCA in the Pisco and Callao record may be explained by stratigraphic problems not identified in the Callao core. Missing sequences and slumped deposits are a common feature in cores retrieved off Peru; consequently overlooking these stratigraphic features could lead to erroneous interpretations (Salvatteci et al., 2014). Another possible explanation for the discrepancy to the Rein et al. $(2004,2005)$ record may be related to the use of the reflectance spectra as an indicator of lithic contents. The present study, in accordance with other lines of evidence (Bradley, 2000; Bradley et al., 2003; Graham et al., 2011), indicates that the MCA in the eastern tropical Pacific was characterized by a range of temperatures, hydroclimate and marine changes. Also note that the record by Rein et al. (2004) is not consistent with these other records (Fig. 3).

\subsection{Peruvian Upwelling Ecosystem response to ocean-atmosphere changes during the last two millennia}

In order to determine the different mechanisms of change affecting the tropical Pacific across centennial timescales, we compare our records from the eastern Pacific with other records representing different processes in the region (Fig. 4). The multiple proxies developed in this study are condensed into four time series representing (1) the oxygenation in the subsurface waters $\left(\delta^{15} \mathrm{~N}\right),(2)$ sediment redox conditions (Re/Mo), (3) primary productivity (biogenic silica), and (4) total export production (represented by an average of the standardized $\mathrm{Ni}$ and $\mathrm{Cu}$ ). $\mathrm{Ni}$ and $\mathrm{Cu}$ may better reflect the original presence of organic matter than TOC that may be altered by post-depositional processes (Tribovillard et al., 2006). These four records are compared to NH temperature reconstruction (Fig. 4a), SST records in the western and eastern Pacific to infer changes in the zonal SST gradient (Fig. 4b 


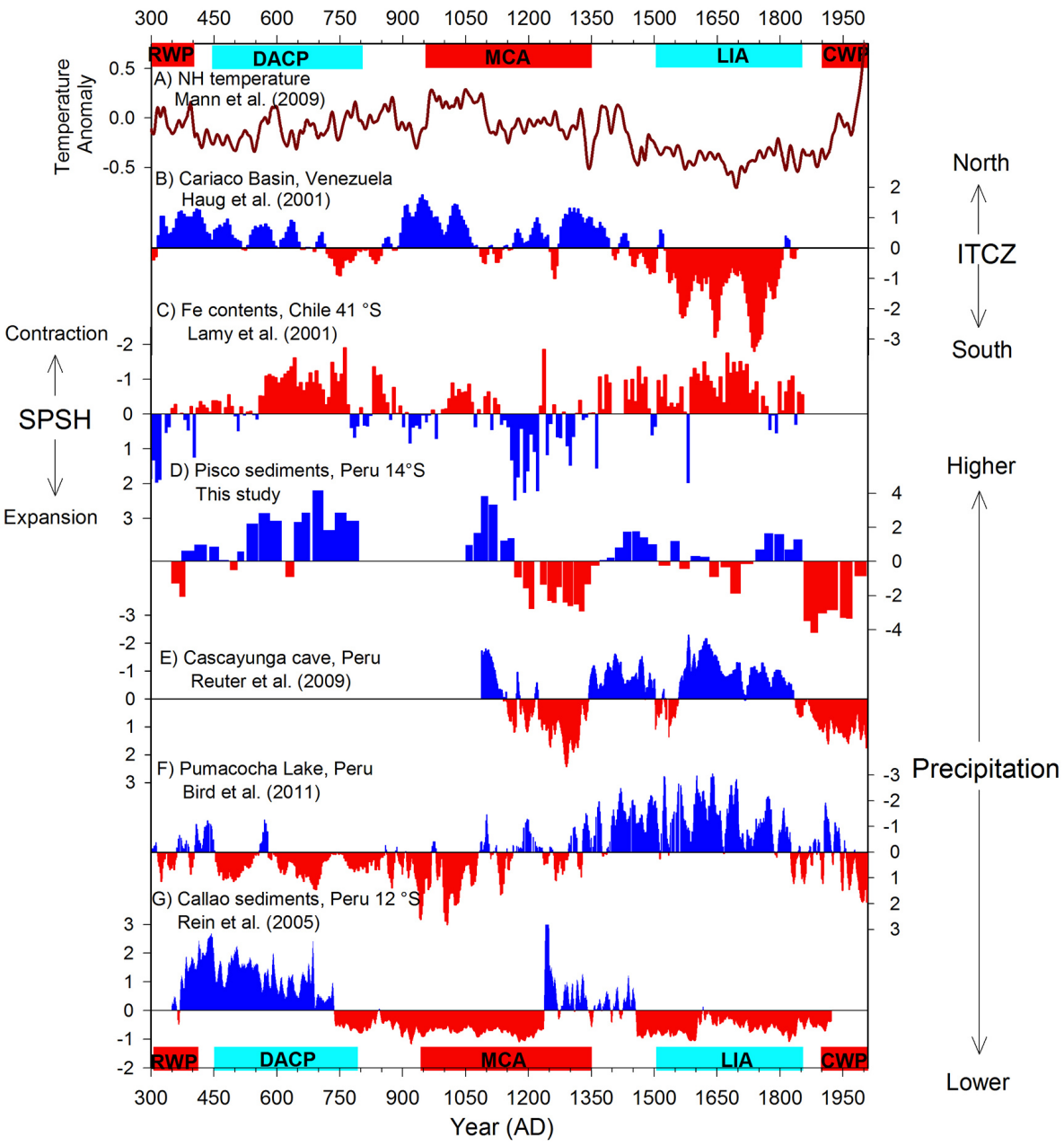

Fig. 3. Precipitation proxies during the last two millennia and selected records from the literature. (A) 10-point average of the "Northern Hemisphere land error-in-variable (EIV) composite" (Mann et al., 2009). (B) 3-point average of Ti \% in Cariaco Basin (Haug et al., 2001). (C) 3-point average of Fe intensity in a marine sediment core off Chile $\left(\sim 41^{\circ} \mathrm{S}\right)$, where higher (lower) values of Fe indicate lower (higher) precipitation and thus a more poleward (equatorward) position of the westerlies. Relative low iron contents are related to enhanced runoff from the iron-poor coastal ranges when the westerlies were positioned over the core position (Lamy et al., 2001). Consequently, a more poleward (equatorward) position of the southern westerlies and the south rim of the SPSH are interpreted to represent a SPSH expansion (contraction). (D) Averaged terrestrial runoff record obtained from the standardized Al and Ti values. (E) 5-point average of Cascayunga cave speleothem rainfall $\delta^{18} \mathrm{O}$ (Reuter et al. 2009), . (F) 5-point average Pumacocha $\delta^{18} \mathrm{O}_{\text {cal }}$ record (Bird et al., 2011). (G) A proxy for lithic concentration in a marine sediment core retrieved off Callao $\left(\sim 12^{\circ} \mathrm{S}\right)$ (Rein et al., 2004, 2005). The series were smoothed using a running mean when indicated and then normalized to a standard $Z$ score. The colored boxes at the top and bottom of the figure indicate the Roman Warm Period (RWP), the Dark Ages Cold Period (DACP), the Medieval Climate Anomaly (MCA), the Little Ice Age (LIA) and the Current Warm Period (CWP).

and c), and with changes in the SPSH expansion/contraction (Fig. 4d).

Our results show that during the NH cold periods (DACP and LIA), the PUE exhibits, in general, a weak OMZ (Fig. 4e), sub-oxic conditions in the sediments (Fig. 4f), and low productivity (Fig. 4g, h), which are characteristic of a more El Niño-like mean state. These features coincide with a weak Walker circulation (Fig. 4b, Oppo et al., 2009; Fig. 4c, Conroy et al., 2010) and a contraction of the SPSH (Fig. 4d, Lamy et al., 2001). The lower productivity is consistent with weak Walker circulation and a deep thermocline, along with a contraction of the SPSH that likely resulted in weaker alongshore winds off central-southern Peru. The cold periods are also characterized by a weak $\mathrm{OMZ}$ and thus a deep oxycline (Fig. 4e). Consequently, the weak upwelling of nutrient-poor waters may have resulted in insufficient fertilization of the upper section of the water column hampering the development of primary producers (Fig. $4 \mathrm{~g}$ ). The productivity from higher trophic levels was low as well, probably as a consequence of low primary productivity (Fig. 4h). 


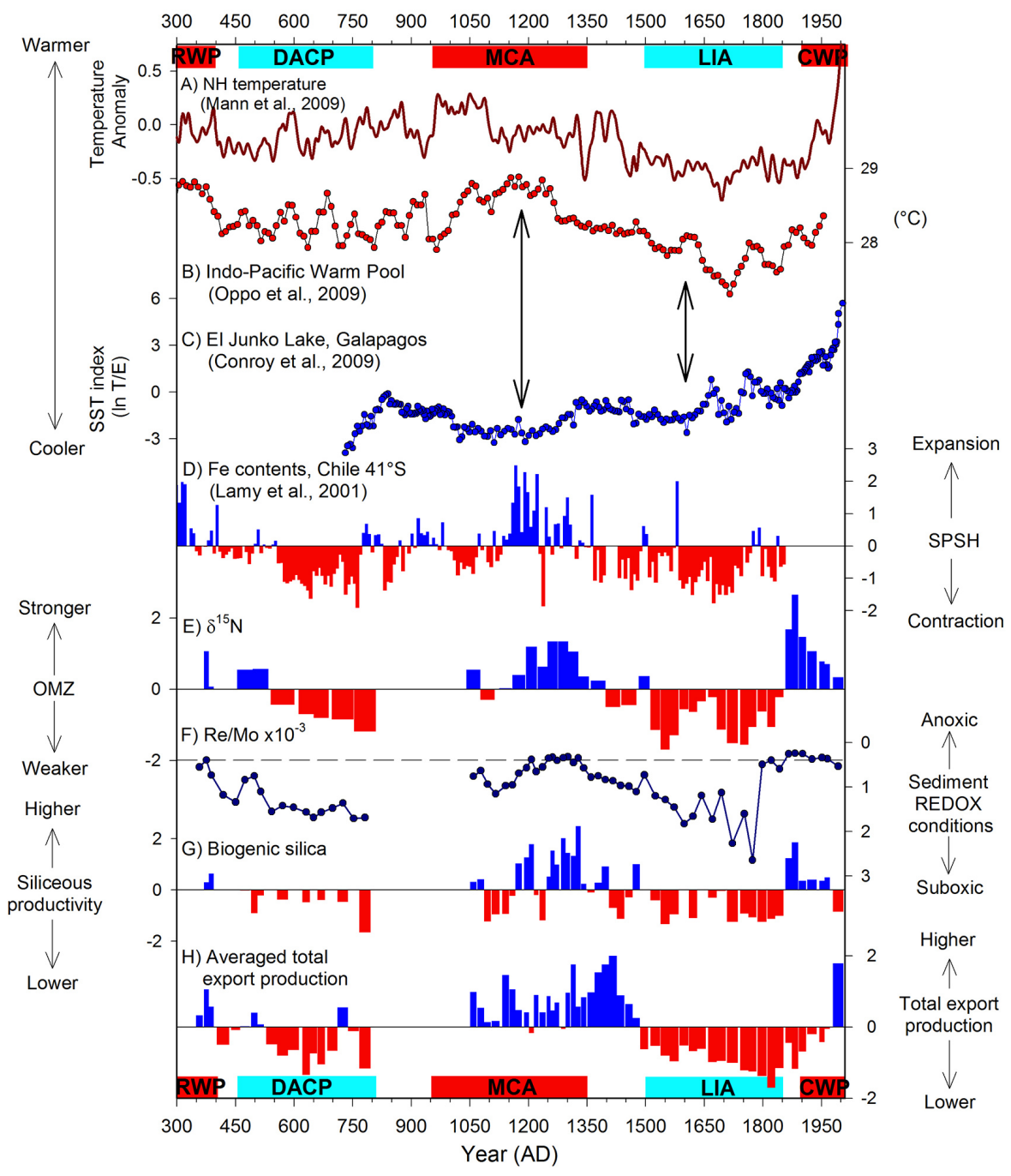

Fig. 4. Linkage between the oxygenation in the subsurface waters and in the sediments, and the export production obtained in the present work and proxies used to infer changes in the zonal SST gradients and changes in the expansion/contraction of the South Pacific subtropical High (SPSH). (A) 10-point average of the "Northern Hemisphere land error-in-variable (EIV) composite" (Mann et al., 2009). (B) Indo Pacific Warm Pool SST reconstruction (Oppo et al., 2009). (C) Eastern Equatorial Pacific SST reconstruction (ln of the number of tychoplanktonic to epiphytic diatoms in El Junco Lake, Galapagos; Conroy et al., 2009). The arrows between these two panels show the increased SST gradient during the MCA compared to the LIA (Conroy et al., 2010). (D) 3-point average of Fe intensity in a marine sediment core off Chile $\left(\sim 41^{\circ} \mathrm{S}\right)$, where higher (lower) values indicate a more poleward (equatorward) position of the westerlies. Relative low iron contents are related to enhanced runoff from the iron-poor coastal ranges when the westerlies were positioned over the core position (Lamy et al., 2001). Consequently, a more poleward (equatorward) position of the southern westerlies and the south rim of the SPSH are interpreted to represent a SPSH expansion (contraction). (E) $\delta^{15} \mathrm{~N}$, proxy for water column denitrification. (F) Re/Mo $\times 10^{-3}$, proxy to differentiate euxinic $\left(\left[\mathrm{O}_{2}\right]=0\right.$; presence of $\left.\mathrm{H}_{2} \mathrm{~S}\right)$ versus sub-oxic conditions, the dashed line indicates the seawater value of $\mathrm{Re} / \mathrm{Mo}=0.4 \times 10^{-3} \mathrm{reported}$ by Crusius et al. (1996). (G) Biogenic silica (\%), proxy for siliceous export production. (H) Averaged total export production obtained from the standardized $\mathrm{Ni}$ and $\mathrm{Cu}$ values. The colored boxes at the top and bottom of the figure indicate the Roman Warm Period (RWP), the Dark Ages Cold Period (DACP), the Medieval Climate Anomaly (MCA), the Little Ice Age (LIA) and the Current Warm Period (CWP).

Both the climatic and oceanographic conditions in the PUE were apparently more extreme during the LIA compared to the recorded part of the DACP (e.g., records in Fig. 2). In contrast to the results of the present study, modern observational data show that when the global ocean and the eastern Pacific cool during La Niña or La Vieja, marine productivity in the eastern Pacific increases at annual or decadal timescales (Chavez et al., 2011). The results of this study suggest that during the NH cold periods (i.e., LIA and DACP) the tropical eastern Pacific was less productive. This apparent contradiction, however, is most likely due to the 
different forcings responsible for cold periods at different timescales.

During the NH warm periods (RWP and the last stage of the MCA), the PUE generally exhibits a strong OMZ (Fig. 4e), anoxic sediment conditions (Fig. 4f), and high productivity (Fig. 4g and h), which is consistent with a $\mathrm{La}$ Niña-like mean state. These features coincide with a stronger Walker circulation (Fig. 4b, Oppo et al., 2009; Fig. 4c, Conroy et al., 2009) and a SPSH expansion (Fig. 4d, Lamy et al., 2001). The strong Walker circulation suggests a shallower thermocline, and an expansion of the SPSH likely produced stronger alongshore winds off Peru. The inferred high productivity and strong $\mathrm{OMZ}$ during the $\mathrm{NH}$ warm periods are consistent with the "ocean thermostat mechanism" proposed by Clement et al. (1996), suggesting that changes in solar irradiance produce changes in the thermocline depth in the eastern Pacific through changes in the Walker circulation strength. The upwelling from nutrient-rich waters resulted in high primary productivity, most likely as a consequence of a stronger Walker circulation and a shallower oxycline (Fig. 4g). Both types of export production proxies show in general higher values during the last stage of the MCA compared to the RWP (Fig. 4g and h), indicating that the climatic and oceanographic conditions during the MCA were more favorable for the productivity off Peru. The clear association of marine productivity and OMZ intensity with changes in ocean-atmosphere systems shows that large-scale circulation changes may have been the driving forces in maintaining productivity and subsurface oxygenation off Peru at centennial timescales during the past two millennia.

Our data demonstrate a strong multidecadal variability of marine productivity and subsurface oxygenation during the recorded part of the MCA associated with changes in the expansion/contraction of the SPSH, whereas the Walker circulation seems to be strong but relatively stable during the entire MCA (Fig. 4b and c). From AD 1000 to AD 1150, relatively low primary productivity and a relatively weak OMZ are observed, coinciding with a stronger Walker circulation (Fig. 4b, Oppo et al., 2009; Fig. 4c, Conroy et al., 2010) and a SPSH expansion (Fig. 4d, Lamy et al., 2001). This suggests that a contraction of the SPSH produced weaker alongshore winds, producing weaker upwelling, lowering the fertilization of the upper water column, and thus producing a relatively low primary productivity even if the Walker circulation was strong (Fig. $4 \mathrm{~b}$ and c). By contrast, during the last stage of the MCA ( $\sim \mathrm{AD} 1150$ to $\sim \mathrm{AD} 1350)$, the primary productivity was high, associated with a strong Walker circulation and an expansion of the SPSH. These conditions may have supported a shallower thermocline and a more stratified water column favoring the productivity in the PUE (Fig. $4 \mathrm{~g}$ and $\mathrm{h}$ ). These results suggest that during the warm periods the contraction/expansion of the SPSH is more important in regulating marine productivity in the PUE than the Walker circulation.
The past 100 years are characterized by a strong OMZ (Fig. 4e) and in general high productivity (Fig. 4g and h) in accordance with former $\mathrm{NH}$ warm periods (RWP and MCA). The overall export production shows a positive trend (Fig. 4h) that could be a result of an increase in upwelling favorable winds (Gutiérrez et al., 2011). Instrumental observations indicate that the Walker circulation and the SPSH experienced important changes during the last decades and may have induced changes in the PUE similar to former warm periods. The westerlies have strengthened and shifted poleward (Toggweiler, 2009; Lee and Feldstein, 2013), while the SPSH has also strengthened, possibly in response to global warming (Falvey and Garreaud, 2009). Moreover, recent observations indicate that the tropical Pacific trade winds have strengthened over the past two decades and likely contributed to the La Niña-like state and enhanced Walker circulation (Luo et al., 2012). However, is not yet clear for the past century whether the increase in marine productivity is principally governed by an intensification of the SPSH (Falvey and Garreaud, 2009) or by an enhancement of local winds due to an increase in land-sea thermal gradients caused by anthropogenic greenhouse gas emissions (Bakun, 1990). The OMZ intensity and productivity during the past 100 years are similar to the pattern observed at the end of the MCA (Fig. 4e-h). In both periods the primary productivity shows a declining trend and the export production from higher trophic levels show an increasing trend. Intriguingly, the sediment redox conditions show a trend towards sub-oxic conditions and the OMZ intensity displays a weakening trend, which is in clear contrast to several studies, suggesting an expansion of the OMZs under the current global warming (Stramma et al., 2008).

\section{Conclusions}

Precipitation, OMZ intensity, sediment redox conditions, and primary productivity, remained strongly coupled during the last two millennia, and were strongly associated with changes in Walker circulation strength and SPSH expansion/contraction as inferred from comparisons with other proxy records. Centennial-scale changes in precipitation are more associated with changes in the ITCZ meridional displacements and SPSH expansion/contraction than changes driven by zonal shifts of precipitation (i.e., ENSO events). On the other hand, productivity and subsurface oxygenation variability are associated with changes in both Walker circulation strength and SPSH expansion/contraction. This indicates that large-scale circulation changes were the driving forces in maintaining productivity and subsurface oxygenation off Peru at centennial timescales during the past two millennia. The observed changes in the PUE are concordant with the "ocean thermostat mechanism" proposed by Clement et al. (1996), suggesting that changes in solar irradiance produce changes in the thermocline depth in the eastern Pacific 
through changes in the Walker circulation strength. In general, $\mathrm{NH}$ warm periods were favorable for productivity in the PUE during the last two millennia.

However, during the MCA, the SPSH expansion/contraction has more influence over the PUE than the Walker circulation changes. During the MCA, the PUE shows at least two stages in relation to the terrestrial runoff, OMZ intensity, sediment redox conditions, and the different types of export production likely driven by changes in the SPSH expansion/contraction and not by changes in the Walker circulation strength. Under the current global warming scenario, an SPSH expansion may likely lead to increased productivity in the PUE.

The PUE was subject of abrupt as well as gradual changes in OMZ intensity and productivity. The transitions from warm to cold periods show a gradual change towards lower productivity and less intense OMZ likely linked to the gradual changes in the global temperatures, a gradual weakening of the Walker circulation, and a gradual SPSH contraction. By contrast, the transition of the PUE from the LIA to the CWP, which lasted about 50 years, was characterized by more abrupt changes.

\section{Supplementary material related to this article is available online at http://www.clim-past.net/10/715/2014/ cp-10-715-2014-supplement.pdf.}

Acknowledgements. We deeply thank the Instituto del Mar del Peru (IMARPE) for full support of this research. We acknowledge the crew of the R/V Jose Olaya Balandra and all scientific participants in the box-coring survey: E. Enríquez, J. Ledesma, R. Marquina, L. Quipuzcoa, J. Solis, F. Velazco and L. Vasquez, without their support this research could not have taken place. We deeply thank Bo Thamdrup, chief scientist of the Galathea-3 expedition (Leg 14), and Bente Lomstein, who conducted the core sampling onboard the RV Vaedderen. We acknowledge F. Le Cornec and J. Cottet for their invaluable help with the ICP-MS analyses. We thank M. Mandeng-Yogo and M. Mendez for the $\delta^{15} \mathrm{~N}$ analyses in core B-14. The AMS radiocarbon measurements were obtained by the "Laboratoire de mesures de C-14" LMC14 (UMS2572, CEA-CNRS-IRD-IRSN-Ministère de la Culture), Gif-sur-Yvette, France, through the IRD financial and technical support to this laboratory. We are grateful to R. Gingold (www.sweepandmore.com) for constructive ideas and editing the manuscript. We are grateful to "Proyecto Cátedra CONCYTEC en Ciencias del Mar-Universidad Cayetano Heredia". We acknowledge support from the project PALEOMAP, the IAEA Coordinated Research Project 12789 (Nuclear and Isotopic Studies of the El Niño Phenomenon in the Ocean), PALEOTRACES project, PALEOPROXUS project and the Chaire croisée PROSUR.

Edited by: L. Beaufort

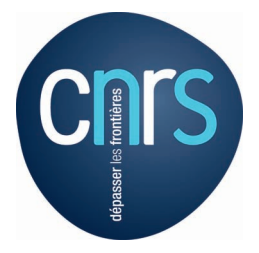

The publication of this article is financed by CNRS-INSU.

\section{References}

Aceituno, P., Fuenzalida, R., and Rosenblüth, B.: Climate along the extratropical west coast of South America, in: Earth system responses to global change, edited by: Mooney, H. A., Fuentes, E. R., and Kronberg, B. I., Academic Press, San Diego, 61-69, 1993.

Agnihotri, R., Altabet, M. A., Herbert, T., and Tierney, J. E.: Subdecadally resolved paleoceanography of the Peru margin during the last two millennia, Geochem. Geophy. Geosy., 9, 1-15, 2008.

Altabet, M. A. and Francois, R.: Sedimentary nitrogen isotopic ratio as a recorder for surface ocean nitrate utilization, Global Biogeochem. Cy., 8, 103-116, 1994.

Altabet, M. A., Pilskaln, C., Thunell, R., Pride, C., Sigman, D., Chavez, F., and Francois, R.: The nitrogen isotope biogeochemistry of sinking particles from the margin of the Eastern North Pacific, Deep-Sea Res. Pt. I, 46, 655-679, 1999.

Appleby, P. G.: Chronostratigraphic techniques in recent sediments, in: Tracking Environmental Change Using Lake Sediments, Volume 1: Basin Analysis, Coring, and Chronological Techniques, edited by: Last, W. M. and Smol, J. P., Kluwer Academic Publishers, Dordrecht, the Netherlands, 2001.

Bakun, A.: Global climate change and intensification of coastal upwelling, Science, 247, 198-201, 1990.

Bakun, A., Field, D., Redondo-Rodriguez, A., and Weeks, S. J. Greenhouse gas, upwelling-favorable winds, and the future of coastal ocean upwelling ecosystems, Global Change Biol., 16, 1213-1228, 2010.

Bertaux, J., Fröhlich, F. and IIdefonse, P.: Multicomponent analysis of FTIR spectra: Quantification of amorphous and crystallized mineral phases in synthetic and natural sediments, J. Sediment. Res., 68, 440-447, 1998.

Bird, B. W., Abbott, M. B., Vuille, M., Rodbell, D. T., Stansell, N. D., and Rosenmeier, M. F.: A 2,300-year-long annually resolved record of the South American summer monsoon from the Peruvian Andes, P. Natl. Acad. Sci., 108, 8583-8588, 2011.

Bjerknes, J. H.: Atmospheric teleconnections from the equatorial Pacific, Mon. Weather Rev., 97, 163-172, 1969.

Böning, P., Brumsack, H. J., Bottcher, E., Schnetger, B., Kriete, C., Kallmeyer, J., and Borchers, S. L.: Geochemistry of Peruvian near-surface sediments, Geochim. Cosmochim. Acta, 68, 44294451, 2004.

Bradley, R.: 1000 years of climate change, Science, 288, 13531355, 2000.

Bradley, R. S., Hughes, M. K., and Diaz, H. F.: Climate in medieval times, Science, 302, 404-405, 2003.

Bratcher, A. J. and Giese, B. S.: Tropical Pacific decadal variability and global warming, Geophys. Res. Lett., 29, 1918, doi:10.1029/2002GL015191, 2002.

Broccoli, A. J., Dahl, K. A., and Stouffer, R. J.: Response of the ITCZ to Northern Hemisphere cooling, Geophys. Res. Lett., 33, L01702, doi:10.1029/2005GL024546, 2006. 
Chavez, F. P. and Messié, M.: A comparison of Eastern Boundary Upwelling Ecosystems, Prog. Oceanogr., 83, 80-96, 2009.

Chavez, F. P., Messié, M., and Pennington, J. T.: Marine primary production in relation to climate variability and change, Annu. Rev. Mar. Sci., 3, 227-260, 2011.

Clement, A. C., Seager, R., Cane, M. A., and Zebiak, S. E.: An Ocean dynamical thermostat, J. Climate, 9, 2190-2196, 1996.

Cobb, K. M., Charles, C. D., Cheng, H., and Edwards, R. L.: El Niño/Southern Oscillation and tropical Pacific climate during the last millennium, Nature, 424, 271-276, 2003.

Colodner, D., Sachs, J., Ravizza, G., Turekian, K., Edmond, J., and Boyle, E.: The geochemical cycle of rhenium: a reconnaissance, Earth Planet. Sc. Lett., 117, 205-221, 1993.

Compo, G. P., Whitaker, J. S., Sardeshmukh, P. D., Matsui, N., Allan, R. J., Yin, X., Gleason, B. E., Vose, R. S., Rutledge, G., Bessemoulin, P., Brönnimann, S., Brunet, M., Crouthamel, R. I., Grant, A. N., Groisman, P. Y., Jones, P. D., Kruk, M. C., Kruger, A. C., Marshall, G. J., Maugeri, M., Mok, H. Y., Nordli, Ø., Ross, T. F., Trigo, R. M., Wang, X. L., Woodruff, S. D. and Worley, S. J.: The Twentieth Century Reanalysis Project. Q. J. Roy. Meteorol. Soc. Pt. A, 137, 1-28, 2011.

Conroy, J. L., Restrepo, A., Overpeck, J. T., Steinitz-Kannan, M., Cole, J. E., Bush, M. B., and Colinvaux, P. A.: Unprecedent recent warming of surface temperatures in the eastern tropical $\mathrm{Pa}$ cific Ocean, Nat. Geosci., 2, 46-50, 2009.

Conroy, J. L., Overpeck, J. T., and Cole, J. E.: El Niño/Southern Oscillation and changes in the zonal gradient of tropical Pacific sea surface temperature over the last 1.2 ka, PAGES News, 18, 32-34, 2010.

Crusius, J., Calvert, S., Pedersen, T., and Sage, D.: Rhenium and molybdenum enrichments in sediments as indicators of oxic, suboxic and sulfidic conditions of deposition, Earth Planet. Sc. Lett., 145, 65-78, 1996.

Dean, W. E., Zheng, Y., Ortiz, J. D., and van Geen, A.: Sediment Cd and Mo accumulation in the oxygen-minimum zone off western Baja California linked to global climate over the past $52 \mathrm{kyr}$, Paleoceanography, 21, PA4209, doi:10.1029/2005PA001239, 2006.

DeMaster, D. J.: The supply and accumulation of silica in the marine environment, Geochim. Cosmochim. Acta, 45, 1715-1732, 1981.

De Pol-Holz, R., Ulloa, O., Dezileau, L., Kaiser, J., Lamy, F., and Hebbeln, D.: Melting of the Patagonian Ice Sheet and deglacial perturbations of the nitrogen cycle in the eastern South Pacific, Geophys. Res. Lett., 33, L04704, doi:10.1029/2005GL024477, 2006.

Echevin, V., Aumont, O., Ledesma, J., and Flores, G.: The seasonal cycle of surface chlorophyll in the Peruvian upwelling system: A modelling study, Prog. Oceanogr., 79, 167-176, 2008.

Falvey, M. and Garreaud, R. D.: Regional cooling in a warming world: Recent temperature trends in the southeast Pacific and along the west coast of subtropical South America (1979-2006), J. Geophys. Res., 114, D04102, doi:10.1029/2008JD010519, 2009.

Garreaud, R. D., Vuille, M., Compagnucci, R., and Marengo, J.: Present-day South American climate, Palaeogeogr. Palaeocl., 281, 180-195, 2009.

Glantz, S. A.: Primer of Biostatistics, McGraw-Hill,New York, 2002.
Graham, N. E., Ammann, C. M., Fleitmann, D., Cobb, K. M., and Luterbacher, J.: Support for global climate reorganization during the "Medieval Climate Anomaly", Clim. Dynam., 37, 12171245, 2011.

Gutiérrez, D., Sifeddine, A., Reyss, J. L., Vargas, G., Velazco, F., Salvatteci, R., Ferreira, V., Ortlieb, L., Field, D., Baumgartner, T., Boussafir, M., Boucher, H., Valdés, J., Marinovic, L., Soler, P., and Tapia, P.: Anoxic sediments off Central Peru record interannual to multidecadal changes of climate and upwelling ecosystem during the last two centuries, Adv. Geosci., 6, 119-125, doi:10.5194/adgeo-6-119-2006, 2006.

Gutiérrez, D., Sifeddine, A., Field, D. B., Ortlieb, L., Vargas, G., Chávez, F. P., Velazco, F., Ferreira, V., Tapia, P., Salvatteci, R., Boucher, H., Morales, M. C., Valdés, J., Reyss, J.-L., Campusano, A., Boussafir, M., Mandeng-Yogo, M., García, M., and Baumgartner, T.: Rapid reorganization in ocean biogeochemistry off Peru towards the end of the Little Ice Age, Biogeosciences, 6, 835-848, doi:10.5194/bg-6-835-2009, 2009.

Gutiérrez, D., Bouloubassi, I., Sifeddine, A., Purca, S., Goubanova, K., Graco, M., Field, D., Méjanelle, L., Velazco, F., Lorre, A., Salvatteci, R., Quispe, D., Vargas, G., Dewitte, B., and Ortlieb, L.: Coastal cooling and increased productivity in the main upwelling zone off Peru since the mid-twentieth century, Geophys. Res. Lett., 38, L07603, doi:10.1029/2010GL046324, 2011.

Haug, G. H., Hughen, K. A., Sigman, D. M., Peterson, L. C., and Rohl, U.: Southward migration of the Intertropical Convergence Zone through the Holocene, Science, 293, 1304-1308, 2001.

Helly, J. and Levin, L.: Global distribution of naturally occurring marine hypoxia on continental margin, Deep-Sea Res. Pt. I, 51, 1159-1168, 2004.

Karstensen, J. and Ulloa, O.: Peru-Chile current system, in: Ocean currents, edited by: Steele, J. H., Thorpe, S. A., and Turekian, K. K., Academic Press, London, 2009.

Kienast, M., Kienast, S. S., Calvert S. E., Eglinton, T. I., Mollenhauer, G., François, R., and Mix, A. C.: Eastern Pacific cooling and Atlantic overturning circulation during the last deglaciation, Nature, 443, 846-849, 2006.

Koffman, B. G., Kreutz, K. J., Breton, D. J., Kane, E. J., Winski, D. A., Birkel, S. D., Kurbatov, A. V., and Handley, M. J.: Centennial-scale shifts in the position of the Southern Hemisphere westerly wind belt over the past millennium, Clim. Past Discuss., 9, 3125-3174, doi:10.5194/cpd-9-3125-2013, 2013.

Koutavas, A. and Lynch-Stieglitz, J.: Variability of the marine ITCZ over the eastern Pacific during the past 30,000 years, in: The Hadley circulation: present, past and future, edited by: Diaz, E. F. and Bradley, R. S., Springer Academic Publishers, Dordrecht, the Netherlands, 2005.

Koutavas, A., Lynch-Stieglitz, J., Marchitto, T. M., and Sachs, J. P.: El Niño-like pattern in ice age tropical Pacific sea surface temperature, Science, 297, 226-230, 2002.

Lafargue, E., Espitalié, J., Marquis, F., and Pillot, D.: Rock-Eval 6 applications in hydrocarbon exploration, production and in soil contaminations studies, Oil Gas Sci. Technol., 53, 421-437, 1998.

Lamb, H. H.: Climate, History and the Modern World, 2nd Edn., Routledge, New York, 1995. 
Lamy, F., Hebbeln, D., Röhl, U., and Wefer, G.: Holocene rainfall variability in southern Chile: a marine record of latitudinal shifts of the Southern Westerlies, Earth Planet. Sc. Lett., 185, 369-382, 2001.

Lavado Casimiro, W. S., Ronchail, J., Labat, D., Espinoza, J. C., and Guyot, J. L.: Basin-scale analysis of rainfall and runoff in Peru (1969-2004): Pacific, Titicaca and Amazonas drainages, Hydrolog. Sci. J., 57, 1-18, 2012.

Lee, S. and Feldstein, S. B.: Detecting ozone- and greenhouse gasdriven wind trends with observational data, Science, 339, 563$567,2013$.

Luo, J.-J., Sasaki, W., and Masumoto, Y.: Indian Ocean warming modulates Pacific climate change, P. Natl. Acad. Sci., 109, 18701-18706, 2012.

Makou, M. C., Eglinton, T. I., Oppo, D. W., and Hughen, K. A.: Postglacial changes in El Niño and La Niña behavior, Geology, 38, 43-46, 2010.

Mann, M. E., Cane, M. A., Zebiak, S. E., and Clement, A.: Volcanic and solar forcing of the Tropical Pacific over the past 1000 years, J. Climate, 18, 447-456, 2005.

Mann, M. E., Zhang, Z., Rutherford, S., Bradley, R. S., Hughes, M. K., Shindell, D., Ammann, C., Faluvegi, G., and Ni, F.: Global signatures and dynamical origins of the Little Ice Age and Medieval Climate Anomaly, Science, 326, 1256-1260, 2009.

Martinez, P. and Robinson, R. S.: Increase in water column denitrification during the last deglaciation: the influence of oxygen demand in the eastern equatorial Pacific, Biogeosciences, 7, 1-9, doi:10.5194/bg-7-1-2010, 2010.

McManus, J., Berelson, W. M., Severmann, S., Poulson, R. L., Hammond, D. E., Klinkhammer, G. P., and Holm, C.: Molybdenum and uranium geochemistry in continental margin sediments: Paleoproxy potential, Geochim. Cosmochim. Acta, 70, 4643-4662, 2006.

Michaels, A. F. and Silver, M. W.: Primary production, sinking fluxes and the microbial food web, Deep-Sea Res. Pt. I, 35, 473490, 1988

Mohtadi, M., Romero, O., Kaiser, J., and Hebbeln, D.: Cooling of the southern high latitudes during the Medieval Period and its effect on ENSO, Quaternary Sci. Rev., 26, 1055-1066, 2007.

Mollier-Vogel, E., Ryabenko, E., Martinez, P., Wallace, D., Altabet, M. A., and Schneider, R.: Nitrogen isotope gradients off Peru and Ecuador related to upwelling, productivity, nutrient uptake and oxygen deficiency, Deep-Sea Res. Pt. I, 70, 14-25, 2012.

Montes, I., Colas, F., Capet, X., and Schneider, W.: On the pathways of the equatorial subsurface currents in the eastern equatorial $\mathrm{Pa}$ cific and their contributions to the Peru-Chile Undercurrent, J. Geophys. Res., 115, C09003, doi:10.1029/2009JC005710, 2010.

Moy, C. M., Moreno, P. I., Dunbar, R. B., Kaplan, M. R., Francois, J.-P., Villalba, R., and Haberzettl, T.: Climate change in southern South America during the last two millennia, in: Past climate variability in South America and surrounding regions, edited by: Vimeaux, F., Sylvestre, F., and Khodri, M., Springer, Dordrecht, the Netherlands, 2009.

Nameroff, T. J., Calvert, S. E., and Murray, J. W.: Glacialinterglacial variability in the eastern tropical North Pacific oxygen minimum zone recorded by redox-sensitive trace metals, $\mathrm{Pa}$ leoceanography, 19, PA1010, doi:10.1029/2003PA000912, 2004.
Newton, A., Thunell, R., and Stott, L.: Climate and hydrographic variability in the Indo-Pacific Warm Pool during the last millennium, Geophys. Res. Lett., 33, 1-5, 2006.

Oppo, D. W., Rosenthal, Y., and Linsley, B. K.: 2,000-year-long temperature and hydrology reconstructions from the Indo-Pacific warm pool, Nature, 460, 1113-1116, 2009.

PAGES 2K Network: Continental-scale temperature variability during the past two millennia, Nat. Geosci., 6, 339-346, 2013.

Partin, J. W., Cobb, K. M., Adkins, J. F., Clark, B., and Fernandez, D. P.: Millennial-scale trends in west Pacific warm pool hydrology since the Last Glacial Maximum, Nature, 449, 452-455, 2007

Pennington, J. T., Mahoney, K. L., Kuwahara, V. S., Kolber, D. D., Calienes, R., and Chavez, F. P.: Primary production in the eastern tropical Pacific: A review, Prog. Oceanogr., 69, 285-317, 2006.

Philander, S. G.: El Niño, La Niña, and the Southern Oscillation, Academic Press, San Diego, California, 1990.

Pierrehumbert, R. T.: Climate change and the tropical Pacific: The sleeping dragon wakes, P. Natl. Acad. Sci., 97, 1355-1358, 2000.

Rein, B., Lückge, A., and Sirocko, F.: A major Holocene ENSO anomaly during the Medieval period, Geophys. Res. Lett., 31, L17211, doi:10.1029/2004GL020161, 2004.

Rein, B., Lückge, A., Reinhardt, L., Sirocko, F., Wolfe, A., and Dullo, W.-C.: El Niño variability off Peru during the last 20,000 years, Paleoceanography, 20, PA4003, doi:10.1029/2004PA001099, 2005.

Rein, B., Sirocko, F., Lückge, A., Reinhardt, L., Wolf, A., and Dullo, W.-C.: Abrupt Change of El Niño Activity off Peru during Stage MIS 5e-d, in: The Climate of Past Interglacials, edited by: Sirocko, F., Claussen, M., Sánchez Goñi, M., and Litt, T., Elsevier, Amsterdam, the Netherlands, 305-321, 2007.

Reinhardt, L., Kudrasss, H.-R., Lückge, A., Wiedicke, M., Wunderlich, J., and Wendt, G.: High-resolution sediment echosounding off Peru: Late Quaternary depositional sequences and sedimentary structures of a current-dominated shelf, Mar. Geophys. Res., 23, 335-351, 2002.

Reuter, J., Stott, L., Khider, D., Sinha, A., Cheng, H., and Edwards, R. L.: A new perspective on the hydroclimate variability in northern South America during the Little Ice Age, Geophys. Res. Lett., 36, L21706, doi:10.1029/2009GL041051, 2009.

Reyss, J. L., Schmidt, S., Legeleux, F., and Bonté, P.: Large, low background well-type detectors for measurements of environmental radioactivity, Nucl. Instrum. Meth. A, 357, 391-397, 1995.

Robinson, R., Kienast, M., Albuquerque, A. S., Altabet, M. A., Contreras, S., De Pol-Holz, R., Dubois, N., Francois, R., Galbraith, E. D., Hsu, T.-C., Ivanochko, T. S., Jaccard, S. L., Kao, S.-J., Kiefer, T., Kienast, S., Lehmann, M., Martinez, P., McCarthy, M., Möbius, J. H., Pedersen, T. F., Quan, T. M., Ryabenko, E., Schmittner, A., Schneider, R., Schneider-Mor, A., Shigemitsu, M., Sinclair, D., Somes, C. J., Studer, A. S., Thunell, R., and Yang, J.-Y. T.: A review of nitrogen isotopic alteration in marine sediments, Paleoceanography, 27, PA4203, doi:10.1029/2012PA002321, 2012.

Rodier, M. and Le Borgne, R.: Export flux of particles at the equator in the western and central Pacific ocean, Deep-Sea Res. Pt. II, 44, 2085-2113, 1997. 
Sachs, J. P., Sachse, D., Smittenberg, R. H., Zhang, Z., Battisti, D. S., and Golubic, S.: Southward movement of the Pacific Intertropical Convergence Zone AD 1400-1850, Nat. Geosci., 2, 519-525, 2009

Salvatteci, R., Field, D., Sifeddine, A., Ortlieb, L., Ferreira, V., Baumgartner, T., Caquineau, S., Velazco, F., Reyss, J. L., Sanchez-Cabeza, J. A., and Gutierrez, D.: Cross-stratigraphies from a seismically active mud lens off Peru indicate horizontal extensions of laminae, missing sequences, and a need for multiple cores for high resolution records, Mar. Geol., in revision, 2014.

Scheidegger, K. F. and Krissek, L. A.: Dispersal and deposition of eolian and fluvial sediments off Peru and northern Chile, Geol. Soc. Am. Bull., 93, 150-162, 1982.

Scholz, F., Hensen, C., Noffke, A., Rohde, A., Liebetrau, V., and Wallmann, K.: Early diagenesis of redox-sensitive trace metals in the Peru upwelling area - response to ENSO-related oxygen fluctuations in the water column, Geochim. Cosmochim. Acta, 75, 7257-7276, 2011.

Sifeddine, A., Gutierrez, D., Ortlieb, L., Boucher, H., Velazco, F., Field, D., Vargas, G., Boussafir, M., Salvatteci, R., Ferreira, V., García, M., Valdes, J., Caquineau, S., Mandeng-Yogo, M., Cetin, F., Solis, J., Soler, P., and Baumgartner, T.: Laminated sediments from the central Peruvian continental slope: A 500 year record of upwelling system productivity, terrestrial runoff and redox conditions, Prog. Oceanogr., 79, 190-197, 2008.

StatSoft: Inc. STATISTICA (data analysis software system), Version 7.1., www.statsoft.com (last access: February 2014), 2005.

Stramma, L., Johnson, G. C., Sprintall, J., and Mohrholz, V.: Expanding Oxygen-Minimum Zones in the Tropical Oceans, Science, 320, 655-658, 2008.

Strub, P. T., Mesias, J. M., Montecino, V., Rutllant, J., and Salinas, S.: Coastal ocean circulation off western South America, in: The Sea, Vol. 11, edited by: Robinson, A. and Brink, K., John Wiley \& Sons, New York, USA, 273-313, 1998.

Suess, E.: Particulate organic carbon flux in the oceans-surface productivity and oxygen utilization, Nature, 288, 260-263, 1980.

Toggweiler, J. R.: Shifting Westerlies, Science, 323, 1434-1435, 2009.

Tribovillard, N., Algeo, T. J., Lyons, T., and Riboulleau, A.: Trace metals as paleoredox and paleoproductivity proxies: An update, Chem. Geol., 232, 12-32, 2006.

Vecchi, G. A., Soden, B., Wittenberg, A. T., Held, I. M., Leetmaa, A., and Harrison, M. J.: Weakening of tropical Pacific atmospheric circulation due to anthropogenic forcing, Nature, 44, 73-76, 2006. 